\title{
FILOSOFÍA Y TEATRO, IDA Y VUELTA. UNA APROXIMACIÓN A JUAN MAYORGA
}

\author{
ALBERTO SUCASAS \\ Universidade da Coruña (UDC)
}

\begin{abstract}
RESUMEN: Aunque el teatro no siempre se haya contado entre los principales objetos de atención de la filosofía, la relación entre filosofía y teatro es relevante. Por varios motivos: frecuente reflexión sobre el teatro a cargo de filósofos; filósofos que han escrito teatro; presencia de interrogantes filosóficos en las obras dramáticas; influencia recíproca de las dos formas de escritura. La obra de Juan Mayorga es un caso ejemplar. Su influencia principal, más aún que Walter Benjamin, es Franz Kafka. La herencia kafkiana se manifiesta en Mayorga, de dos maneras: formalmente, en la práctica de una «ética de la escritura teatral», la cual intenta eliminar de la escritura dramática cualquier forma de dogmatismo; y desde el punto de vista del contenido, mediante la omnipresencia de la intersubjetividad poderoso/ impotente en su escena teatral.
\end{abstract}

PALABRAS CLAVE: teatro; poder; Mayorga; Kafka; Benjamin.

\section{Philosophy and theatre, round trip. An approach to Juan Mayorga}

ABSTRACT: Although theatre has not been always considered among the main objects of attention of philosophy, the relationship between philosophy and theatre has been relevant. For several reasons: frequent reflection on the theatre by philosophers; philosophers who have written theatre; presence of philosophical questions in dramatic works; reciprocal influence of the two forms of writing. The work of Juan Mayorga is an exemplary one. His main influence, even more than Walter Benjamin, is Franz Kafka. The Kafkian heritage is manifested in Mayorga in two ways: formally, in the practice of an "ethic of theatrical writing", which attempts to eliminate any form of dogmatism from dramatic writing; regarding the content, through the omnipresence of powerfull/impotent intersubjectivity in its theatrical scene.

KEY WORDS: theatre; power; Mayorga; Kafka; Benjamin.

\section{INTRODUCCIÓN}

De procederse a un inventario, más o menos exhaustivo, de los temas mayores que, en el transcurso de dos milenios y medio, han ocupado a la filosofía occidental, muy probablemente el hecho teatral no se contaría entre ellos. Sin estar por entero ausente del logos filosófico, el logos teatral parece haber sido, para aquel, objeto de una atención, si no marginal, sí al menos periférica.

No obstante, aun asumiendo esa presencia modesta, no cabría resolver el binomio filosofía-teatro proclamando su insignificancia. Cuando menos por cuatro órdenes de razones.

En primer término, la relativa frecuencia con que los filósofos han emprendido una meditación sobre el teatro. El repertorio, sin resultar abrumador, es a todas luces significativo; limitémonos a algunas referencias señeras: desde la crítica platónica del arte (República), incluido el escénico, y la reflexión aristotélica sobre la tragedia (Poética), pasando por Rousseau (Carta a d'Alembert sobre los espectáculos), Lessing (Dramaturgia hamburguesa) y Nietzsche (El 
nacimiento de la tragedia), hasta propuestas de pensadores contemporáneos como Lukács (Metafísica de la tragedia), Ortega (Idea del teatro), Benjamin (El origen del drama barroco alemán), Goldmann (El dios oculto), Szondi (Tentativa sobre lo trágico) o Badiou (Rapsodia por el teatro). En esos clásicos, la dramaturgia es elucidada desde interrogantes genuinamente filosóficos, en un espacio problemático donde convergen inquietudes ontológicas (estatuto ficcional del espectáculo), gnoseológicas (examen crítico de la pretensión de verdad inherente al teatro) y filosófico-prácticas (efectos ético-políticos de la representación). Coexisten, como es natural, con la tematización específicamente estética. Incluso cabría decir que la interpretación de lo trágico constituye una suerte de subgénero filosófico entre cuyos cultivadores se cuentan, aparte de los ya citados, algunos nombres mayores en la historia del pensamiento de los dos últimos siglos: no solo el idealismo alemán (Schelling, Hegel, Hölderlin), Schopenhauer o Kierkegaard, sino también espíritus como Unamuno, Simmel, Scheler o Jaspers.

Un segundo grupo de evidencias lo proporciona la práctica de la escritura teatral en el gremio filosófico. Sin excluir el probable precedente platónico (se dice que el filósofo, antes de devenir tal, habría escrito piezas trágicas; según la leyenda, el giro biográfico provocado por el encuentro con Sócrates le habría inducido a quemarlas), se impone destacar nombres como Séneca, Maquiavelo (La mandrágora), Voltaire, Diderot, Lessing, Marcel o Sartre. Señalemos que, en la mayoría de los casos, no estamos ante dos procesos de escritura heterogéneos e inconexos, sino más bien ante una inspiración unitaria que se bifurca en dos modalidades textuales. Un indicio de afinidades latentes entre logos filosófico y logos teatral.

Lo confirma, en tercer término, la densa presencia de la filosofía, de sus preguntas y perplejidades, en buena parte de la producción dramática de la Weltliteratur. La tragedia ática habría inaugurado una «contaminación filosófica» de la escena que, a lo largo de los siglos, no ha cesado de crecer, haciendo que la dialéctica de la idea discurra pareja al agón dramático. Baste evocar nombres como Calderón, Goethe, Schiller, Hölderlin, Ibsen, Eliot, Beckett o Buero Vallejo. Se diría que nociones cardinales en la cultura de Occidente (libertad, verdad o justicia se contarían entre ellas) se han forjado, y persisten en ello, bajo la doble tutela del discurso (filosófico) y la escena (teatral).

Pero, indiquémoslo para concluir, no solo asistimos a una penetración del trabajo del concepto en el ámbito teatral. Se da igualmente la trayectoria inversa; algunos logros mayores de la reflexión filosófica han nacido de la acogida hospitalaria de motivos oriundos de la esfera dramática: ciñéndonos a tres ejemplos, señalemos cómo la tragedia fecundó la ética aristotélica de la phrónesis o, mucho más tardíamente, el proyecto dionisíaco de Nietzsche, su pensamiento trágico; otro tanto hizo el Trauerspiel respecto a la elaboración benjaminiana de la alegoría. Pero ese préstamo, que hace a la filosofía deudora del teatro, no solo ha operado a nivel material (en el plano de los contenidos doctrinales), sino también en la esfera de las formas. Aunque de una manera velada, que a menudo encubrió el débito, la escritura de la filosofía evidencia, 
en uno de sus géneros hegemónicos, una genealogía teatral. Nos referimos, por supuesto, a la forma-diálogo: desde su fundación platónica (notablemente paradójica: el pensador que condenó la ficción artística nunca dejó de ser su fértil heredero) hasta el polílogo derridiano, ha servido de cauce expresivo a muchos de los momentos histórico-filosóficamente mayores en la andadura del logos. En la complicidad entre escritura dialógica y esfuerzo dialéctico se condensa la simbiosis filosófico-teatral.

Esa cuádruple constatación invita a reconocer la más que notable singularidad de uno de los corpus más valiosos de nuestra literatura reciente: la obra de Juan Mayorga.

\section{ENTRE FILOSOFÍA Y TEATRO}

Matemático y filósofo, docente (de Matemáticas primero, en la enseñanza secundaria; de Dramaturgia y Filosofía, más tarde, en la madrileña Real Escuela Superior de Arte Dramático) y dramaturgo, adaptador y director de escena, miembro de grupos de investigación filosófica y asiduo conferenciante, partícipe en proyectos escénicos renovadores y animador de publicaciones vinculadas al teatro... la personalidad intelectual de Mayorga sorprende, en primera instancia, por su extraordinaria diversidad. Con todo, en ese denso panorama, no resulta difícil reconocer dos requerimientos principales: filosofía y teatro; teatro y filosofía. Más aún, se impone afirmar que toda su actividad nace de la sinergia entre ambos territorios: Mayorga habita la frontera que, a la par, los vincula y diferencia, convencido de «hasta qué punto los caminos del teatro y la filosofía son para mí uno solo» ${ }^{1}$.

Primera evidencia: la duplicidad del corpus mayorguiano. Por un lado, la ensayística filosófica: una espléndida monografía sobre Walter Benjamin, Revolución conservadora y conservación revolucionaria ${ }^{2}$, que versiona su tesis doctoral de 1997, y la extensa recopilación Elipses. Por otro, la producción dramática: tratándose de un corpus en formación, sería prematuro, e imprudente, presagiar su alcance íntegro; limitémonos a señalar que la edición de sus obras mayores hasta 2014 (que no incluye ni las piezas breves ni las numerosas

1 Mayorga, J., Elipses. Ensayos 1990-2016, La Uña Rota, Segovia, 2016, p. 13. La declaración, extraída del prólogo de la obra, ostenta un carácter marcadamente programático. Abre un horizonte en el que también se han inscrito iniciativas académicas reseñables: a comienzos de la presente década, durante tres años, Mayorga dirigió, en el Instituto de Filosofía del CSIC el seminario Memoria y pensamiento en el teatro contemporáneo (la ambición de ese proyecto consistió en «abrir un lugar y un tiempo de encuentro en que filosofía y teatro - probablemente de forma conflictiva, como es propio de dos ámbitos que nacen y viven del conflicto- se conozcan y se interroguen. Que la filosofía desafíe al teatro, que el teatro desafíe a la filosofía, ese es el objetivo último de esta propuesta»); en la actualidad, dirige una Cátedra de Artes Escénicas en la Universidad Carlos III.

2 Cf. Mayorga, J., Revolución conservadora y conservación revolucionaria. Política y memoria en Walter Benjamin, Anthropos, Rubí (Barcelona), 2003. 
adaptaciones) configura un voluminoso libro, ¡de casi ochocientas páginas! ${ }^{3}$ Sin embargo, no son las dimensiones cuantitativas, por significativas que en sí mismas resulten, la clave principal para elucidar el proyecto intelectual, filosófico-teatral, de Mayorga. Lo esencial reside, más bien, en el dato cualitativo de que allí confluyen, sin por ello renunciar a sus respectivas idiosincrasias, lo filosófico y lo teatral. ¿Síntesis?; ¿hibridación o mestizaje?; ¿sinergia?; ¿contaminación recíproca?; ¿maridaje?; ¿interdisciplinariedad?... Quizá aporte mayor iluminación una metáfora muy querida del Mayorga matemático ${ }^{4}$ : las dos vertientes o sectores de su obra trazan una elipse cuyos dos focos serían filosofía y teatro. "Filosofía y teatro»: en ese sintagma importaría tanto la conjunción que los une («y») como los dos sustantivos que lo integran.

De hecho, Mayorga encarnaría ejemplarmente (un poco a la manera en que Hölderlin y Nikolái Leskov lo fueron para Heidegger y Benjamin, respectivamente, en tanto que referentes modélicos para determinar la naturaleza de la poesía y de la narración $)^{5}$ el binomio filosofía-teatro que intentamos abordar desde el comienzo. En cada uno de los cuatro aspectos señalados.

En primer lugar, la adopción del hecho teatral, en toda su complejidad (no solo estética, también — quizá se impusiese decir: ante todo- ético-política), como objeto privilegiado de reflexión. De ello ofrecen abundante confirmación los textos de Elipses, que vuelven reiteradamente sobre su naturaleza específica y su función histórica. En ambos aspectos, la complicidad con la filosofía es decisiva. Desde supuestos mayorguianos, la raíz común de esas dos prácticas culturales reside en su vocación política. Grecia sería, también aquí, referencia fundacional: en la polis ateniense nacieron, o adquirieron temprano pero maduro desarrollo, filosofía y teatro; allí prosperaron dos modos dialógicos del habla, en forma de discusión pública en el ágora (interlocución socrática que el discípulo adaptaría a la escritura) o de agón trágico en el proscenio. Esa confrontación en el medio verbal conservaría, en nuestro presente cívico, toda su vigencia. Si el proyecto de la filo-sofía anhela una episteme apta para acallar el bullicio de la doxa dominante en el espacio público, no otro es el designio del teatro. Desvelar, sobre el escenario, la falacia del poder y sus acólitos: «Olvidan que el teatro nació precisamente para interrogar a los dioses. Y para desenmascarar a los hombres que se disfrazan de dioses $»^{6}$.

3 Cf. Mayorga, J., Teatro 1989-2014, La Uña Rota, Segovia, 2015². Le acompaña, a manera de hermano menor, Teatro para minutos. 28 piezas breves (Ñaque Editora, Ciudad Real, 2009).

4 No solo da título a su recopilación de ensayos. Los textos vuelven una y otra vez, desde una inspiración benjaminiana, sobre el potencial heurístico de esa metáfora geométrica. No en vano las seis secciones del libro llevan estos títulos: «Focos»; «Ejes»; «Intersecciones»; «Tangentes»; «Par»; «Elipse de elipses».

5 Nos referimos, obviamente, a los ensayos «Hölderlin y la esencia de la poesía» y «El narrador».

6 Mayorga, J., Elipses, op. cit., p. 131. Un dato contextual («Quizá lo más interesante de algunos de estos textos sea la fecha en que fueron escritos o pronunciados», ibid., p. 13): la declaración forma parte de un breve Manifiesto para el Día Mundial del Teatro de la Plataforma Cultura contra la Guerra (27.03.2003). 
Asimismo, en segundo término, por la masiva presencia de lo filosófico en la escritura teatral de Mayorga, un filósofo que escribe - y dirige- teatro. Ya desde los títulos de algunos de sus textos, que bien pueden «citar», en una intertextualidad filosófico-teatral no exenta de voluntad irónica («Emmanuel Can» es, en El jardín quemado y La paz perpetua, nombre de perro), textos canónicos (La paz perpetua; Manifiesto comunista) o momentos decisivos (Angelus Novus remite al dibujo de Klee que inspiró a Benjamin su «ángel de la historia») de la historia de la filosofía, o aludirlos de manera implícita (así, la pieza Tres anillos remite al Natán el sabio, obra filosófico-teatral de Lessing que Mayorga adaptará); igualmente, un término tan repleto de connotaciones categoriales como Justicia da nombre a una pieza breve. Otro tanto ocurre con nombres de personajes: Blumenberg en El traductor de Blumemberg o la viuda Kolakowski en Concierto fatal de la viuda Kolakowski. Para no demorarnos en la frecuencia con que interrogaciones filosóficas clásicas (sobre la existencia de Dios, por ejemplo) o contemporáneas (en El chico de la última fila se reitera el dilema planteado por George Steiner en un célebre ensayo: ¿Tolstói o Dostoievski?) se inmiscuyen en el intercambio dramático. No obstante, lo esencial no reside en esos momentos lúdicos o de ironía intertextual, sino en la masiva presencia, en forma por supuesto dramatizada, de cuestiones filosóficas en la dramaturgia de Mayorga. Incluso cabría decir que esta consiste, fundamentalmente, en metabolizar, para la escena, motivos filosóficos. Acaso la trinidad Verdad-MemoriaJusticia sea el sustrato categorial que discretamente vertebra ese corpus teatral.

Conviene, empero, despejar un posible equívoco: Mayorga no es solo un filósofo que reflexiona sobre el teatro y escribe teatro; tampoco sería suficiente añadir que lo filosófico habita su escritura teatral. En él, el nexo filosofía-teatro es de ida y vuelta: en lugar de establecer un vínculo disimétrico, donde lo filosófico mantuviese una hegemonía incuestionada, promueve más bien un préstamo recíproco, un vaivén constante entre espacio lógico y espacio escénico. No solo, pues, el injerto de nociones filosóficas en la representación teatral o la sostenida meditación sobre esta; también la impronta, clandestina pero rotunda, de la poética teatral en la escritura filosófica.

Algo que ilustra paradigmáticamente el estudio monográfico sobre Benjamin. En apariencia, estaríamos ante un escrito que, siguiendo las convenciones de la prosa académica (no en vano en su origen está una tesis doctoral), se adentra en la intrincada propuesta filosófica de uno de los grandes clásicos de la pasada centuria, Walter Benjamin; la interpretación recurriría a una metódica comparativa, pues el universo categorial del filósofo alemán es confrontado con los de tres «hermanos enemigos»(Jünger, Schmitt, Sorel). A ese triple paralelo se añadiría, en el último capítulo de la obra ( $V I$. El topo en la historia: la esperanza en un mundo sin progreso»), una aproximación, en sintonía con la lectura benjaminiana, al universo narrativo de Kafka. Exceptuando de momento el tratamiento de este, la estructura de la obra promueve tres parejas filosófico-políticas: Benjamin-Jünger, Benjamin-Schmitt y Benjamin-Sorel. ¿Mero balance de coincidencias y divergencias entre un selecto puñado de contemporáneos? Sin dejar de serlo, le subyace, alentando su despliegue discursivo, un 
enfoque dramático: Mayorga se propone reconstruir, en efecto, el drama de la modernidad y, en orden a lograrlo, pone en pie una «escena categorial» donde un personaje principal (Benjamin) se confronta con tres antagonistas. Las afinidades que con cada uno de ellos sin duda mantiene, a pesar de las innegociables diferencias, no hacen sino potenciar la fuerza dramática del constructo. Dicho de otro modo: permitiendo que la escritura filosófica se contagie de un espíritu dramatúrgico, Mayorga propone, sin abandonar el elemento del concepto, un agón filosófico-teatral. Y, en consecuencia, consiente que la escritura teatral contamine, sin abolirla, la lógica de la escritura filosófica. Revolución conservadora y conservación revolucionaria es un texto cripto-teatral. Algo ya sugerido por el propio título, en una suerte de retruécano semántico.

Digamos que esa «teatralización»o «dramatización» de la filosofía domina el talante intelectual de Mayorga, también cuando cultiva el ensayo: al igual que en la sala teatral se contraponen, antitéticamente, personajes que encarnan posiciones existenciales y políticas irreductibles, sin síntesis apaciguadora, la escritura filosófica de Mayorga rehúye el tono doctrinario o dogmático al que tan proclive ha sido, cuando se dejó seducir por la compulsión al sistema, el logos filosófico. Y no para recaer en un relativismo escéptico: la voluntad de verdad, irrenunciable, vertebra todo su discurso, pero el sentido crítico (y, lo que es más valioso, incondicionalmente auto-crítico) impide que ese anhelo, absolutamente filo-sófico, se pervierta en una prematura proclamación de la Verdad allí donde la interrogación mantiene su desafiante incertidumbre. Nada, pues, de teatro de tesis: el hecho teatral no puede importar una verdad venida de fuera (del continente filosófico), porque ese exterior nunca deja de ser fiel a la irreversible problematicidad de cualquier presunta certeza. En formulación programática:

«Cuando escribo en modo alguno me pongo en la situación «Soy un escritor de izquierdas». Todo lo que intento es ejercer mi libertad. Ese empeño, previo a cualquier posición política concreta, es una posición política. Creo que antes que predicar la libertad hay que ejercerla, y que el modo natural en que un artista contribuye a la extensión de la libertad - y combate el autoritarismo y la docilidad- es ejerciendo la suya ${ }^{7}$.

A través de su teatro filosófico y su filosofía dramatizada, en insistente travesía de ida y vuelta, Mayorga pone en práctica su convicción nuclear, la única que es objeto de una adhesión categórica: una voluntad de verdad indisolublemente ligada al imperativo de (auto-)crítica.

7 Mayorga, J., Elipses, op. cit., p. 83. De ese mismo ensayo provienen estas consideraciones: «A mi juicio, una cultura que se pretenda resistente contra el dominio del hombre por el hombre ha de comenzar en la sospecha de sí misma. Ha de comenzar vigilando su propia inclinación al autoritarismo y a la docilidad: ha de comenzar por preguntarse cuáles son sus señores y sus siervos, cuáles sus obediencias y sus intereses. (...) Solo una cultura crítica respecto de sí misma podría agitar la crítica hacia el mundo y no ser leal compañera de la barbarie» (ibid.). 


\section{2. ¿BENJAMin O KaFKa?}

Se ha vuelto tópico, entre estudiosos, críticos y comentaristas, caracterizar el corpus literario de Mayorga como un «teatro benjaminiano». Sin duda, no escasean razones para ello: al lado de préstamos literales y citas más o menos encubiertas que salpican sus piezas, argumentos, situaciones y personajes dramatizan motivos extraídos del autor del Passagen-Werk. Entre los temas mayores de esa dramaturgia se cuentan, sin duda, algunos de los principales nudos problemáticos del corpus benjaminiano: la superposición de barbarie y civilización en los hechos culturales; el anhelo de redimir el lenguaje - degradado, para decirlo bíblicamente, tras la Caída y la Catástrofe babélica- y el papel que en esa restauración desempeñaría la práctica de la traducción; la urgencia de recuperar la memoria de los vencidos y, por tanto, exhumar el pasado sepultado por el dominio de los vencedores; la contraposición entre objetividad historiográfica y memoria mesiánica; la desolada imagen de la historia como escenario de una acumulación creciente de dominación del hombre por el hombre; los efectos devastadores de la tecnificación de la existencia... El propio dramaturgo no oculta el papel que en su producción juega el filósofo alemán como presencia tutelar:

«Soy deudor de Benjamin, hasta el punto de que la autointerpretación de mi trabajo le es deudora. Hay motivos, estrategias y fines de mi trabajo, tanto filosófico como teatral, que han sido ahormados por Benjamin. Por ejemplo, la figura de la traducción que es fundamental en mi teatro, la meditación sobre la violencia, la centralidad del pasado fallido, todos esos son motivos benjaminianos» ${ }^{8}$.

Sería imposible poner en entredicho ese vínculo genealógico. Sin embargo, bien podría ocurrir que otra figura capital del pasado siglo, que despertó la pasión interpretativa de Benjamin y ha acompañado la trayectoria creadora de Mayorga, desplazase a aquel, sin por ello expulsarle, de su privilegiada posición. Nos referimos a Franz Kafka.

Mayorga le ha consagrado dos ensayos soberbios ${ }^{9}$, en los que ofrece variaciones sobre un único tema: el poder, visto desde la perspectiva de quien, careciendo de él, lo sufre. Poder sufrido, que no ejercido: tal es —según Mayorga- el centro de lo kafkiano. La grandeza del praguense no consistiría sino en la asunción, lúcida y consciente, de su inextirpable pequeñez, pero no en la forma de una aceptación resignada, de cuño estoico, sino como reivindicación consciente y deliberada:

8 «Juan Mayorga: las obsesiones de un matemático y autor de éxito», entrevista de Rocío García, El País, 1 de junio de 2016.

9 Aparte del capítulo ya reseñado de Revolución conservadora y conservación revolucionaria, el trabajo, escrito en colaboración con Reyes Mate, «"Los avisadores del fuego": Rosenzweig, Benjamin y Kafka» (en Mate, R. [ed.], La filosofía después del Holocausto, Riopiedras, Barcelona, 2002, pp. 77-104). La sección final (pp. 94-104) está íntegramente dedicada al praguense. 
«Si Kafka ha sido elevado a la categoría de primer testigo de la modernidad quizá sea porque la indiferencia y el miedo son las experiencias fundamentales del hombre moderno. En Kafka se reducen a una sola, la experiencia kafkiana fundamental: la experiencia que hace del poder el que no lo tiene, el impotente. La experiencia de la humillación —que no es la experiencia de la humildad. Lo asombroso es que Kafka hace de esa experiencia fundamento de esperanza.

El gran tema de Kafka es el poder» ${ }^{10}$.

Proponemos considerar la última frase de la cita como una confesión indirecta: $m i$ [de Juan Mayorga] gran tema es el poder. Dos corpus literarios, los de Kafka y Mayorga, vendrían a ser sendas ondas expansivas que se propagan (narrativa, diarística y epistolarmente en Kafka; dramatúrgica y filosóficamente en Mayorga) desde un breve texto del primero, La carta al padre. El nexo paternofilial escenifica ahí, a partir de la experiencia vivida del hijo, la desigualdad irreductible entre un sujeto que encarna la Ley inflexible, e inflexiblemente culpabilizadora, y otro a quien corresponde identificarse, en el desamparo de su carne, con la culpa humillante. Lo notable de Kafka, insiste Mayorga, reside en que no propone invertir esa intersubjetividad signada por la dominación, sino iluminarla, y en la medida de lo posible propiciar su extinción, desde la fidelidad incondicional al punto de vista del dominado. De ahí las figuras de la debilidad que, en forma humana o animal (el bestiario es uno de los ingredientes irrenunciables del imaginario kafkiano), pueblan los relatos del praguense. De ahí, también, la relevancia del animal (el Mono Blanco de Últimas palabras de Copito de Nieve y la Harriet de La tortuga de Darwin son sus paradigmas) en las creaciones de un Mayorga empeñado en denunciar «la aniquilación moral y física de los seres humanos; la animalización de los hombres, su reducción a cuerpo vulnerable» ${ }^{11}$.

De Kafka se ha dicho, insistentemente, que su modo existencial predominante fue la soledad. Lo corroboraría el testimonio de Gustav Janouch:

«- ¿Tan solo se siente?

Kafka asintió.

—¿Igual que Gaspar Hauser?

Kafka rio y dijo:

—Mucho peor que Gaspar Hauser. Yo estoy solo... como Franz Kafka» ${ }^{12}$.

\footnotetext{
10 MAYORga, J., Revolución conservadora y conservación revolucionaria, op. cit., pp. 243244.

11 Mate, R., y Mayorga, J., “Los avisadores del fuego": Rosenzweig, Benjamin y Kafka», art. cit., p. 103. Sin hacer de ella objeto de elaboración explícita, una antropología de la debilidad o el desamparo (el hombre en tanto que ser infinitamente vulnerable y, por ende, siempre susceptible de ser dañado) parece subyacer a la obra de Mayorga.

12 Janouch, G., Conversaciones con Kafka. Notas y recuerdos, trad. de R. Sala, Destino, Barcelona, 1997, p. 135. Esa declaración dio título a una notable monografía de Marthe Robert: Solo, como Franz, Kafka (1979).
} 
Si bien esa experiencia de la soledad pudo marcar la biografía kafkiana, lo cierto es que, en su analítica del poder desde la visión del vencido o humillado, Kafka no estuvo solo. La suya fue una intuición compartida. Quienes la asumieron no formaban una tendencia cultural organizada, menos aún una escuela... ni siquiera un grupo generacional. Sin embargo, desde su aparente dispersión, esa pléyade de espíritus constituyó lo que, valiéndonos de un término del léxico benjaminiano, podríamos denominar una constelación. La integraron personalidades que, provenientes del judaísmo emancipado, articularon una crítica del poder, de su capacidad destructiva de la subjetividad humana, desde supuestos ético-políticos, más o menos implícitos (en algunos casos, así ocurre con Simone Weil, esa fidelidad al judaísmo diríase inconsciente, involuntaria: en la superficie de sus escritos, Israel es objeto de un rechazo incondicional), de la tradición hebrea. Con otras palabras: supieron extraer de la experiencia del exilio y la apatridia, de la supervivencia comunitaria sin Estado pero fiel al Libro, un non serviam exento de violencia.

No nos es dado identificar en su integridad las estrellas que configuran esa constelación, pero sí nombrar algunas de las más rutilantes, humildemente rutilantes. Figuran literatos como Broch, Canetti, Albert Cohen o Celan (los dos primeros igualmente podrían ser catalogados como pensadores, dado el excepcional alcance de su producción ensayística), pero también artistas (Chaplin) o filósofos (la Weil o Levinas). Partiendo de circunstancias y proyectos muy dispares, todos ellos comparten una convicción nuclear, susceptible de formularse en forma de ecuación: PODER = MAL. El poder es el Mal. Ese axioma establece un distanciamiento irreversible de cualquier manifestación del poder o la fuerza, adquiera o no rango institucional, y problematiza, en consecuencia, la supervivencia misma de lo político (o, de no ser así, plantea una utopía política: la de un poder exento de dominación ${ }^{13}$. Pues ya no cabe distinguir entre dos formas del poder — una mala y execrable, la otra buena y loable-; por bienintencionadas que sean sus pretensiones, esa propuesta dual, que sin duda atraviesa cualquier formulación programática de lo político, lejos de extirpar el mal lo reproduce de manera inevitable. La ilusión, exasperada en el mito revolucionario de las políticas emancipatorias, se incuba allí donde la idea de un contra-poder, convocado a eliminar la dominación, no hace sino prolongarla, por cuanto, creyendo adueñarse de un instrumento neutral, se somete sin quererlo a su lógica implacable.

13 En Mayorga daría lugar a la tensión, irresuelta, entre la vocación política de su teatro y la desoladora constatación de la coacción, deshumanizadora, indisociable del ejercicio de todo poder. Otra elipse, perturbadora e inquietante. Esa tensión, o aporía, reaparece, a poco que se profundice en sus propuestas, en todos los miembros de la constelación. Es patente en Levinas, cuya ética de la alteridad absoluta, pretendiendo a la vez impugnar por tiránica la esfera de lo político y legitimarla en su versión liberal, se adentra en parajes de lo insoluble: cf. Sucasas, A., «Márgenes del Estado. Una lectura levinasiana de Samuel I» (en id., Memoria de la Ley. Ensayos sobre pensamiento judio, Riopiedras, Barcelona, 2002, pp. 71-96) y «Difícil política. Justicia y mesianismo en Levinas» (en id., Celebración de la alteridad. Cinco ensayos levinasianos, Lilmod/Prometeo, Buenos Aires, 2014, pp. 159-196). 
A esa quimera de una «superación política de la política» oponen los apologetas de la debilidad otro programa: solo cabe sustraerse a la lógica del poder, a su congénita perversidad, reivindicando la perspectiva de quien lo sufre, del débil o impotente, del vencido. El precio a pagar es la renuncia a cualquier ejercicio de la fuerza. Pero, entonces, ¿qué resta de la necesidad, a todas luces evidente, de un aparato institucional regulador, y transformador, del vivirjuntos? Tal es el talón de Aquiles del paradigma de la impotencia. También representa la frontera que excluye a Benjamin de su constelación: no porque él no reivindique los derechos del vencido (su filosofía política no pretende otra cosa), sino porque al hacerlo políticamente estaría perpetuando el mal que se propuso erradicar.

La antinomia (condena del poder, sea cual sea, en tanto que modo de dominación vs. necesidad del poder como instancia articuladora del hecho social) es, más que probablemente, irresoluble. Esa extrema problematicidad habita la dramaturgia de Mayorga. Pero en ella prevalece, si nuestra lectura es acertada, el enfoque kafkiano (no abandonar jamás la posición del dominado y, en consecuencia, abstenerse de toda complicidad con el poder) sobre el benjaminiano (recurrir a la buena violencia —revolucionaria y mesiánica: «divina», llegará a afirmar Para una crítica de la violencia - para instaurar definitivamente, en un estado social donde se aproximan, hasta la indistinción final, las promesas de las revoluciones modernas y el imaginario de la paz mesiánica, un orden social ajeno a toda violencia).

¿Temas benjaminianos en el teatro de Mayorga? Sin duda, pero filtrados por un tamiz kafkiano, que los transforma. Con otras palabras: aquellos serían sub-temas que, a manera de planetas y satélites, describen sus respectivas trayectorias alrededor de una presencia solar, la crítica del poder. Ese sería el tema de Mayorga. En tal medida, su obra, la integridad del corpus, constituiría un vástago tardío de la constelación o tradición de la impotencia, respecto a la cual Kafka representa el momento constituyente y su Carta al padre el texto fundacional. (Aunque su prehistoria remita, como sugerimos, a la tradición ético-religiosa del judaísmo.)

Así pues, la crítica (no-política) del poder, la reivindicación de la impotencia, instituye el centro inspirador. Su irradiación opera en una doble dimensión dentro de la producción teatral. Desde un punto de vista material o de contenido, se traduce en la representación dramatúrgica del poder, en forma de intersubjetividad dual, acentuadamente bi-polar, donde se enfrentan, sin mediación posible, poderoso e impotente. Pero, a nivel formal, promueve una paradójica ética de la escritura teatral, de suerte tal que la impronta kafkiana no se limita a dar voz, sobre la escena, al desposeído de todo poder, sino que contagia la propia voz del autor, la escritura de Juan Mayorga.

Comenzaremos por esa singular asunción de la autoría, asintóticamente tendente al debilitamiento y la renuncia. 
3. Ética de La escritura teatral

Mal de autor; desazón de la autoría. Así podemos enunciar la peculiar relación, recelosa y (auto-)crítica, que el Mayorga dramaturgo mantiene con su propia vocación literaria. Como si la escritura hubiese de estar siempre bajo sospecha. ¿Cuál puede ser su mal congénito, su pecado original?

Justamente, el denunciado por la constelación de la impotencia: no hay creación literaria donde, cualquiera que sea su contenido, no asome un gesto de poder, ante todo en virtud del monopolio de la palabra que la soledad de la escritura presupone. Leer (o asistir a una representación escénica) es someterse, en cuanto receptor de la obra, a lo dicho por otro, sumiéndose el lector en una situación de estricta heteronomía. Ubi auctor, ibi auctoritas. Sus afinidades electivas con Kafka impiden a Mayorga asumir con buena conciencia su condición de autor; sin renunciar a la escritura, ha introducido en su práctica un momento, determinante, de inquietud o resquemor, en virtud del cual su literatura vive del permanente auto-cuestionamiento, como si cada frase hubiese de coexistir con la amenaza de su borrado o surgiese de la borradura de las que la precedieron... a la espera de ulteriores borrados.

¿Auctor sine auctoritate? Ese lema formula un programa de imposible ejecución, condenado a la aporía. En lugar de eludirla, Mayorga la incorpora a su trabajo literario, sometido a la infinita tensión entre un momento afirmativo (lo dicho por el dramaturgo) y la erosión irrenunciable de la negatividad ${ }^{14}$. Como si hubiese de resultarle posible hablar y callarse, o desdecirse, a la vez, su dramaturgia se instala, con trágica lucidez, en ese double bind. Hasta esbozar una utopía de la escritura, consistente en depurar la palabra de su designio autoritario y, purificada, devolverle su complicidad con el silencio. Se diría que el acto de nombrar, exento de violencia, debiese rendir tributo a lo que resta innominado. Desafío abisalmente aporético: ¿cómo poner en pie un habla silenciosa, una escritura cuyos trazos respetasen la blancura virginal de la página? Esa cura de humildad, fomentadora de una ascética literaria, se alía con un imperativo heterológico, cuyo cometido principal es operar una fisura en la identidad del escritor y, a través de ella, permitir que la irrupción del Otro desquicie el ensimismamiento, proclive al dominio, de la palabra solitaria. (Algo sin duda favorecido por una peculiaridad del hecho teatral: a diferencia de otras manifestaciones literarias, en él lo textual solo representa una de sus facetas, por decisiva que resulte.)

14 Ese gesto, que no respeta las fronteras entre géneros literarios, es familiar a otros representantes de la constelación de la impotencia. Así, el ritmo triádico (dicho-desdicho-vuelto a decir) que Levinas propone adoptar en la prosa filosófica; asimismo, la formulación lírica de Celan en Habla tú también: «Habla - / pero no separes el no del sí. / Da a tu proverbio también sentido: / dale sombra. (...) Verdad dice quien sombra dice» (Celan, P., Obras completas, trad. de J. L. Reina Palazón, Trotta, Madrid, 1999, pp. 108-109). 
¿Cómo se pone en obra esa voluntad de elaborar el hecho literario desde una impotencia deseada? En Mayorga, activa una metódica que comprende seis estrategias básicas.

1. El doblete teatro-filosofía posibilita que la escritura dramática se vea acompañada, con propósito vigilante, por un pensamiento (auto-)crítico. De ahí la recurrencia, a manera de leitmotiv, de esta frase: ¿quién escribe mis palabras? ${ }^{15}$ En las páginas de Elipses es objeto de una reiteración al borde de la obsesión: no se trata del motivo, teorizado por Bloom, de la «ansiedad de la influencia» (aquí prevalece un narcisismo literario que reafirma, hasta la exasperación, la voluntad de originalidad y, por ende, de autoría), sino, muy al contrario, del auto-cuestionamiento del escritor que sabe de las trampas a que está sujeta su finitud. ¿Cómo, en efecto, asegurarse de que el propio acto de escritura no vehicule, sin saberlo, estereotipos de la doxa dominante, de tal modo que, creyéndose enunciación inaugural, en realidad sea mera caja de resonancia del poder, su portavocía involuntaria? ¿Cómo, con otras palabras, alcanzar la certeza de que el habla literaria no es, bajo su superficie creativa, un ejercicio inconsciente de ventriloquía? No caben certidumbres definitivas. Solo el trabajo incesante de la sospecha, del recelo, de la mala conciencia. Nace de la humildad: de aceptarse la extrapolación de una noción teológica al ámbito literario, podría decirse que en el corpus de Mayorga alienta una inclinación kenótica, cuyo paradigma vendría dado por el auto-vaciamiento cristológico (kénosis) que la encarnación del Hijo llevó a cabo.

2. Lógica del in-acabamiento: allí donde el autoritarismo de la escritura se ha ausentado, ya no cabe pensar en formulaciones definitivas. Se impone, más bien, una incesante tarea de re-escritura. Mayorga versiona una y otra vez sus textos, siempre abiertos a nuevas formulaciones. Sin que ello resulte, ante todo, de un prurito perfeccionista; el estímulo proviene de fuera: haciéndose pública, la obra (y esto es especialmente cierto del teatro, donde lo textual es tan solo promesa de la representación futura) ha dejado de ser propiedad exclusiva del autor, quien desde ese momento, renunciando al monopolio, comparte su creación con otros muchos (actores; directores de escena; crítica y público). En la escena teatral, el autor se ve confrontado, de manera ineludible, con el Otro. Mayorga lo celebra y por eso repudia reservarse el derecho a la última palabra: «La reescritura precede a la escritura. Cuando un escritor escribe una palabra, ha desechado dos» ${ }^{16}$.

3. Esa actitud hospitalaria hacia el Otro tiene consecuencias en el modo de concebir, y practicar, la relación entre lo textual y lo escénico. De hecho, la parquedad se impone, como precepto general, en las acotaciones escénicas del corpus mayorguiano. El gesto intensifica la dialéctica expropiadora que el dramaturgo decide imprimir a sus piezas: en vez de predeterminar las decisiones

15 Títulos de dos textos de Elipses: «¿Quién escribe estas palabras» (pp. 83-84); “¿Quién escribe nuestras vidas?» (pp. 373-377).

16 Mayorga, J., Elipses, op. cit., p. 101. 
de puesta en escena y la labor actoral, mediante indicaciones prolijas, Mayorga opta por crear un texto que facilite la indeterminación de sus representaciones; renuncia a regularlas de antemano.

4. Apología del espectador. Mayorga lo dignifica hasta hacer de él verdadero protagonista del espectáculo dramático. Late ahí el legado benjaminiano, pues en ambos casos asistimos al primado del receptor, a cuyo servicio se diseña una modalidad de escritura que le interpela y requiere: «De acuerdo con Benjamin, cada lector ha de buscar ante cada texto una estrategia orientada a la desarticulación, despliegue y consumación de dicho texto. Toda la obra de Benjamin —no solo sus piezas más fragmentarias- está escrita para un lector productivo ${ }^{17}$. Esa orientación, sin duda afín a los supuestos de la Escuela de Constanza (estética de la recepción), alcanza expresión en desarrollos teóricos:

«El teatro no sucede en el escenario, sino en el espectador, en su imaginación y en su memoria — la cual es también, finalmente, imaginación—» ${ }^{18}$.

Pero su enunciación también corre a cargo de personajes; especialmente aquellos a quienes la pieza asigna funciones meta-teatrales, directas (el Acotador de Hamelin) o indirectas (Volodia, en El crítico, es un crítico teatral inmerso en un agón con su antagonista, el dramaturgo Scarpa):

«ACOTADOR: Hamelin es una obra sin iluminación, sin escenografía, sin vestuario. Una obra en que la iluminación, la escenografía, el vestuario, los pone el espectador ${ }^{19}$.

VOLODIA: Empiezo a imaginar los personajes interpretados de otro modo, el espectáculo dirigido de otra forma, otro texto. Poco a poco, en mi cabeza crece una obra distinta de la que está en el escenario. Una obra mayor que la que está en el escenario» ${ }^{20}$.

Acaso sea en Hamelin donde esa celebración del receptor alcanza, al menos desde una visión escenográfica, su máxima expresión: preocupado por fomentar espectadores maduros, intelectual y estéticamente exigentes, cuya imaginación activa sea el verdadero lugar donde se represente la obra, el dramaturgo opta por un extremo minimalismo de la puesta en escena, que obliga al espectador -únicamente auxiliado por un Acotador- a devenir escenógrafo del espectáculo que está contemplando. Lugares, objetos y situaciones de la acción son nombrados por el texto, pero no materializados, como presencias visibles, en el escenario; el público es invitado a suplir ese déficit. Axioma mayorguiano: el teatro pobre (Grotowski ocupa un lugar destacado en el panteón teatral de Mayorga) enriquece al espectador.

5. Una penúltima estrategia persigue romper, momentánea o duraderamente, la ilusión de autosuficiencia del espectáculo, su clausura en una inmanencia

\footnotetext{
17 Mayorga, J., Revolución conservadora y conservación revolucionaria, op. cit., p. 10.

18 Mayorga, J., Elipses, op. cit., p. 88.

19 Mayorga, J., Hamelin, en id., Teatro 1989-2014, op. cit., p. 396.

20 Mayorga, J., El crítico, en ibid., p. 582.
} 
autocomplaciente. La meta-teatralidad está muy presente (Más ceniza, El jardín quemado, Himmelweg, El arte de la entrevista, Reikiavik, Famélica... entre otras muchas piezas) cuando el personaje, desdoblándose, interpreta a otro personaje. Esa mise en abîme, contra lo que a primera vista pudiera pensarse, no pretende blindar la ficción escénica, encerrándola en una espiral interminable, sino, al contrario, evidenciar su artificio: por medio de la representación de la representación, el trabajo reduplicador no redunda en la absolutización del espectáculo sino en su debilitamiento crítico. Quizá ese efecto debilitador resulte máximo, aunque efímero, cuando los personajes, dando por un instante la espalda a sus papeles, miran directamente al público y le interpelan (Himmelweg, Hamelin, El chico de la última fila o La paz perpetua). En el que hasta el presente acaso haya sido el mayor logro de Mayorga (no solo como autor, también como director de escena: el minimalismo es extremo, en un escenario casi vacío y donde se impone la monocromía del rojo; tan solo dos actores, Blanca Portillo y José Luis García-Pérez, interpretan a una docena de personajes), hay un momento excepcional, de un paradójico dramatismo, pues el espectador es hondamente conmovido justamente cuando el espectáculo impugna su propio artificio, exhibiéndolo en lugar de ocultarlo para preservar la ilusión realista: la Niña, de repente, deja de ser tal y se convierte en Blanca Portillo, una actriz que desde el escenario reconoce la imposibilidad de su propia representación; ni ella ni su compañero pueden hacer que reviva en la sala teatral la experiencia del gueto varsoviano; se esfuerzan cada noche en transmitir al público algo de aquella experiencia, pero se saben incapaces de resucitarla ${ }^{21}$. Entonces pronuncia estas palabras:

«No somos un anciano y una niña. Y, sobre todo, no estuvimos allí. ¿Tenemos derecho a representar a estos personajes? Nos lo preguntábamos cada día en la sala de ensayos: ¿tenemos derecho a representar a estos personajes? Un día, cuando llegamos a esta escena, tuvimos que parar. No podíamos representar esta escena. Aquella mañana, en la sala de ensayos, decidimos que nos lo preguntaríamos antes de cada función, y durante cada función: ¿tenemos derecho a representar a estos personajes? También decidimos que nunca intentaríamos representar esta escena. Solo podemos decirla $»^{22}$.

6. Un último procedimiento para atenuar la autoría: desdoblarla, de suerte tal que la duplicación tenga un efecto debilitador (el más — dos autores, que no

21 En ese instante maravilloso, donde la representación teatral alcanza el clímax exhibiendo su propia impotencia, no solo late el malestar de la autoría omnipresente en la escritura de Mayorga; más específicamente, aflora ahí uno de los desafíos más extremos que ha debido asumir el arte en las últimas siete décadas: la (im)posibilidad de la representación cuando la creación se propone revivir el Mal absoluto del exterminio nazi. Himmelweg insiste en esa misma problematicidad abisal.

22 Palabras dichas, que no escritas: solo tienen entidad durante la representación, estando ausentes de las tres versiones escritas que poseemos del texto. Agradecemos al autor el permiso para reproducirlas. También la confidencia de que no las integrará en ediciones futuras de la obra. Esa decisión deriva, sin duda, de la ética de la escritura teatral: la autoría del texto se ve erosionada por su Otro escénico. 
uso solo- deviene en menos, en déficit de autoría; como si el paradójico complemento filosófico, llamado a enriquecer el texto teatral, contribuyese también a su empobrecimiento o desposesión). O sea, construir una elipse editorial: en los últimos años, Mayorga ha decidido acompañar la edición de piezas singulares con un epílogo, a cargo de un filósofo, que prolonga en el comentario conceptual el texto literario. Reikiavik, Famélica y El cartógrafo (Varsovia, 1:400.000) han contado con la glosa de, respectivamente, Fernando Broncano («Intercambio de reinas»), Reyes Mate («El motín de la anécdota») y Alberto Sucasas («Cartografía teatral»).

\section{ESCENAS DE PODER}

Pero lo que hemos dado en llamar «ética de la escritura teatral» no agota la crítica del poder omnipresente en esta dramaturgia. Apenas representa su faceta reflexiva, en tanto que auto-crítica del elemento de dominación inherente al acto de escritura. Resta analizar su dimensión representativa; a saber, la escenificación o dramatización del poder, su representación teatral. Se impone afirmar que ese motivo es omnímodo en el corpus mayorguiano. Nunca ausente, casi siempre ocupa el centro del nudo dramático. Puede tratarse de un poder revestido de sanción institucional (Stalin en Cartas de amor a Stalin; el Comandante de Himmelweg; el Profesor y el Doctor, representantes en La tortuga de Darwin del poder académico y sanitario sobre Harriet; el Inquisidor de La lengua en pedazos; los funcionarios interrogadores de El cartógrafo) o de carácter más bien informal (el invisible Max en Más ceniza; Garay, el psiquiatra de El jardín quemado; el Claudio de El chico de la última fila, armado de su capacidad de observación y su habilidad en la escritura; el Bajo de Animales nocturnos que, desde su estatus de ciudadano, chantajea al extranjero ilegal; Volodia, cuyo juicio crítico le otorga ascendiente sobre el dramaturgo Scarpa; incluso el Flaco de El gordo y el flaco desempeñaría en cierto modo ese papel respecto a su partenaire, el Gordo). La anterior relación, lejos de ser exhaustiva, deja constancia de la centralidad del poder en el imaginario teatral de Juan Mayorga. Sin constituir una regla irrestricta, bien cabe afirmar que buena parte de su producción resulta de la confrontación, del agón, entre dos personajes definidos por su heterogénea relación con el poder: uno de ellos lo ostenta; el otro, careciendo de él, es su víctima. En tal medida, la dramatización del poder describe una intersubjetividad asimétrica, cuyos dos polos son el poderoso y el débil.

Desde esa premisa puede deducirse la necesidad de una segunda matización crítica a la caracterización del teatro de Mayorga como teatro político. De los dos males mayores en que se cifra el daño histórico (la desigualdad que, efecto de la explotación, ha condenado a la mayoría de los hombres a sobrevivir en un estado de permanente insatisfacción de la necesidad; la dominación, que atenta contra la voluntad libre) en nuestro autor predomina, sin discusión, el segundo. Sin que por ello se ignore el primero: la diferencia de clase no está ausente, 
sin duda. Basta evocar piezas como Animales nocturnos (contraste entre los dos matrimonios, el de autóctonos y el de inmigrantes), Hamelin (la miseria en que malvive la familia de Josemari) o El chico de la última fila (disparidad entre una familia acomodada y un muchacho de extracción popular), para no decir nada de la brutal explotación colonial denunciada por los monjes de Primera noticia de la catástrofe. Con todo, si bien el criterio socio-económico a menudo acompaña al ejercicio del poder, es este el que reclama máxima atención.

En su analítica del poder, esa dramaturgia explora, sobre todo, los efectos devastadores, por igual en la esfera íntima de la individualidad y en la pública de lo social, que acarrea la dominación. Sugerimos la distinción entre dos temas mayores, a cada uno de los cuales acompañan, antitéticamente, dos contra-temas en los que se abren paso los compromisos axiológicos de mayor calado en Mayorga.

El poder provoca, en el límite, la anulación del sujeto individual en tanto que subjetividad libre. De hecho, como la microfísica del poder de Foucault proclamó sin descanso, hace de la subjetividad una figura de la sujeción. Tan es así que los personajes que encarnan impotencia o debilidad, vulnerabilidad o humillación, son vaciados de su propia sustancia para ser colonizados, en una intimidad que ha dejado de serlo, por el poderoso. El motivo foucaultiano de la «capilaridad» ilumina la escena mayorguiana: el poder no se reduce a una fuerza brutal que presiona desde el exterior; su logro máximo consiste, más bien, en invadir, hasta saturarla, la interioridad del dominado. Literalmente, está en todas partes, inscribiendo su ley sobre cuerpos y espíritus. Eso muestran, por ejemplo, el Max (a la vez omnipresente en la trama argumental e invisible sobre la escena, a manera de un deus absconditus) de Más ceniza, que ha logrado imponer su voluntad en las conciencias de los tres protagonistas masculinos (Darío, José y Abel), o, ejemplarmente, el Stalin de Cartas de amor a Stalin, que transforma al Bulgákov inicial, reivindicativo y rebelde, en guiñapo psíquico cuya identificación con el fantasma del tirano no conoce resquicios. El Yo del poderoso anula el yo de aquel a quien sojuzga; en El Golem incluso se juega con la posibilidad, amparada por técnicas biomédicas, de injertar en una mente contenidos psíquicos provenientes de otra. En cualquier caso, allí donde la dominación triunfa se extingue la espontaneidad de las facultades anímicas (inteligencia; voluntad; afectividad) definitorias de la individualidad humana. Incluso en sujetos dotados de poder; basta con que obedezcan a un superior para que su singularidad agonice. Es el caso del Comandante en Himmelweg: cuando Gottfried/Gershom, el líder judío, sugiere la posibilidad de una rebelión ( ¿¿y si no hacemos lo que usted desea? ¿Y si no cumplimos sus deseos?»), su respuesta expresa inequívocamente que también él se concibe a sí mismo como un instrumento de "Berlín», instancia suprema de dominio en el Reich: «¿Mis deseos? ¿Crees que yo tengo deseos, Gershom? Berlín me ha elegido. Igual que a ti. Berlín nos ha elegido» ${ }^{23}$.

23 Mayorga, J., Himmelweg, en id., Teatro 1989-2014, op. cit., p. 328. 
No obstante, por implacable que sea su representación teatral del poder, Mayorga no es un poeta de la desolación. En su obra anida la esperanza, surgida de la "organización del pesimismo». (Aunque convenga tomar la observación con cautela, quizá podría incluso hablarse de cierta progresión de la esperanza, avalada por el contraste entre un texto temprano, como Cartas de amor a Stalin, donde la devastación del débil, el literato Bulgákov, se consuma, y la tenaz resistencia de Teresa en La lengua en pedazos, el Anciano y la Niña de El cartógrafo, o también la pícara Harriet de La tortuga de Darwin). Sin por ello oponer al poder bárbaro un contra-poder asimismo violento (los insurgentes del Gueto de Varsovia sí lo hicieron, pero el anciano cartógrafo desafía pacíficamente a los genocidas elaborando mapas), al débil le cabe resistir enarbolando la fidelidad a su propio proyecto de conciencia libre. Ya el mero reconocimiento del poder como dañino preserva, incluso en personajes cuya conciencia ha sucumbido a una enajenación inducida, un residuo de voluntad insubordinada y, por ende, una promesa de futura resistencia. Así ocurre en Darío, víctima del perverso Max, cuando declara con notable crudeza verbal su repulsa del poder:

«A mí la política me la suda. Mande quien mande, la gente como yo estamos jodidos porque estamos para eso, para estar jodidos mientras otros mandan. No pienses en ellos, Regine, solo son mierda ${ }^{24}$.

Cuando la escena de la dominación comparece en toda su obscena desnudez, sin tapujos ni veladuras, la palabra de la resistencia se vuelve más lúcida y clara. A la coacción del Inquisidor, quien no duda en transitar de la persuasión ( Quiero que vos misma cerréis la casa») a la amenaza ( Si vos no cerráis esta casa rebelde, seré yo quien lo haga. Y esta misma noche buscaré justicia para vos»), replica, sin orgullo pero con resolución, la conciencia libre de Teresa de Ávila:

«Se hizo esta casa porque el Señor lo mandó y solo se deshará si él lo manda $»^{25}$.

¿De dónde extrae el espíritu que resiste su capacidad, exenta de violencia, de insumisión? ¿En nombre de qué se formula la palabra de resistencia? Dar respuesta a esos interrogantes nos acerca al segundo contra-tema positivo. Entenderlo aconseja realizar un excurso histórico-literario. En la tradición premoderna, la duplicidad en la dignidad de los personajes (nobles o vulgares) exigía un tratamiento diferenciado: los primeros, heroicamente idealizados, eran objeto de un discurso elevado (épico o trágico), mientras que para los segundos se reservaba un tratamiento cómico, satírico o burlesco. Esa poética de la desigualdad, sin duda reflejo de una estratificación social axiomáticamente jerárquica (mucho reconocimiento para unos pocos; escaso, o nulo, reconocimiento para los muchos), se preservó intacta hasta que el espíritu igualitario de la modernidad, que en lo político se tradujo en el reemplazo del Antiguo

24 Mayorga, J., Más ceniza, en ibid., pp. 88-89.

25 Mayorga, J., La lengua en pedazos, en ibid., p. 550. 
Régimen por un orden republicano y, más tarde, en la voluntad emancipatoria de los movimientos socialistas, introdujo un vuelco revolucionario en la república de las letras: el estilo serio y grave debía aplicarse a personajes populares, del común, al tiempo que las varias aristocracias (de la sangre, de las armas, del altar) se volvían merecedoras de un tratamiento cómico ${ }^{26}$. Esa nueva mentalidad, que el género novelesco consagró tempranamente, llegó más tarde a la literatura dramática; no obstante, el empuje de autores como Diderot o Lessing consiguió consolidarla. Del drama burgués al teatro brechtiano, el impulso igualitario inherente al espíritu moderno adquirió expresión en la dramaturgia. Mayorga es un heredero tardío, pero radical, de ese proceso. Hasta el punto de que el compromiso con la igualdad esencial de todos los hombres (o sea, la reivindicación escénica de la dignidad de cualquiera) se convierte en segundo contra-tema: si la aniquilación del sujeto perpetrada por el poderoso chocaba con su límite en la resistencia del impotente que no cede, lo que en esta se abre camino es, justamente, la reivindicación de la dignidad de cualquiera. El agón teatral es trasunto de la lucha por el reconocimiento:

«GERMÁN: Ya sabemos de la infinita mezquindad de la clase media. Ya se sabe que la clase media es fea, banal, estúpida. También lo era la aristocracia rusa, pero Tolstói se las arregló para escribir Ana Karenina. Y Dostoievski, ¿'sabes el secreto de Dostoievski? Hacer de personas vulgares personajes inolvidables» ${ }^{27}$.

El secreto de Dostoievski radicaría, precisamente, en sondar el secreto que todo sujeto, cualquiera, esconde tras una apariencia vulgar o banal. Afirmar el valor absoluto de la persona humana: ese compromiso dramatúrgico transmite, literariamente, idéntico pensamiento al formulado por Kant, en la jerga filosófico-práctica, al proclamar que el imperativo categórico obliga a tratar la humanidad, en cualquier hombre, siempre como fin y nunca como medio. En ese sentido, el Martín de Los yugoslavos, que regenta un modesto bar, es un kantiano impenitente:

«MARTÍN: A usted le parecerá ridículo, pequeño, vivir así. El mostrador, las mesas, los manteles de papel. Le parecerá vulgar, sin brillo, sin gracia. (...) Pero eso no es todo. Cada día sucede algo. Suceden cosas. A un cliente le paga la consumición un desconocido. ¿Por qué? Misterio. Pequeñas cosas. (...)

26 Esa apretada síntesis histórica reclama una matización de notable alcance. Como demostró Auerbach en su obra maestra Mimesis, la irrupción del cristianismo en el mundo antiguo ya conmocionó la dualidad estilística: su testimonio principal, los relatos evangélicos, introdujo una mutación revolucionaria en la historia literaria, al abordar con el tono sublime de lo trágico una acción cuyos protagonistas procedían del común. Una nueva confirmación de cómo la secularización moderna reitera, en un plano de inmanencia histórica, motivos originariamente teológicos: la fraternidad universal instituida por la Encarnación (hermanos en Cristo; hijos del Padre) constituye el precedente cristiano de la axiomática igualitaria de la modernidad.

27 Mayorga, J., El chico de la última fila, en id., Teatro 1989-2014, op. cit., p. 440 [cursiva nuestra]. 
Uno rompe un vaso aposta. ¿Por qué? Misterio. Entra un chaval buscando a alguien, lo encuentra, una mujer muy guapa, parece que el chaval va a decirle algo pero se va sin decir ni pío. Lo comentábamos. Cosas. Lo inesperado. Todo es siempre igual, pero cada día pasa algo. Solo hay que estar atentos. Cada cliente es un misterio. Yo aquí he conocido santos y criminales. Aquí hay canallas que piensan sus crímenes y personas que se sacrifican por otros ${ }^{28}$.

No elevarse de lo ordinario a lo extraordinario, sino impugnar ese dilema desvelando lo extraordinario que late en lo ordinario, como si el denostado gris contuviese, semioculta, la integridad del espectro cromático. Pero captarla requiere la mirada kantiana de hombres grises como Martín. La dramaturgia de Mayorga la posee.

Un tema (la subjetividad del poderoso devastando la del débil) y dos contratemas (resistencia del impotente; absoluto de la dignidad individual).

Pero la crítica teatral de la dominación promueve otra tríada, también ella acorde con ese triángulo dialéctico: un motivo (triunfo social de la violencia y la mentira) y dos anti-motivos (palabra y libro en tanto que instancias de redención; memoria que rescata el pasado encubierto). Transitamos de una ética de la individualidad a la traducción teatral del viejo programa de crítica de la ideología.

Letal para la pervivencia de una subjetividad libre, cuya iniciativa autónoma es incompatible con la sumisión, el poder tampoco tolera la existencia de criterios de verdad independientes: fuente de coacción física, generadora de cuerpos dóciles $^{29}$, requiere también de un dominio sobre las conciencias, pues la nuda violencia, carente de legitimidad, no garantiza su estabilidad. De ese imperativo brota la institucionalización de un dispositivo donde falsedad y violencia modelan, sinérgicamente, el hecho social.

El universo dramático de Mayorga es particularmente sensible a la institucionalización de la mentira. José, en Más ceniza, expresa cómo la destrucción de la subjetividad, hasta no saber quién se es, resulta de la mendacidad inherente al dominio, de su eficaz imposición de la impostura:

«JOSÉ: Al saltar de aquel avión en llamas, supe que tendría que mentir. Pero no sabía que duraría tanto. En cuanto puse pie en tierra, empecé a mentir, y no he parado de hacerlo. He olvidado quién soy. Así trabaja la mentira,

28 Mayorga, J., Los yugoslavos, en id., Teatro 1989-2014, op. cit., p. 664.

29 Mayorga ha insistido en la relevancia del cuerpo en tanto que objeto del dominio. Si, con Merleau-Ponty, la fenomenología exploró la experiencia del cuerpo propio, la crítica del poder muestra cómo este deviene impropio, hasta instaurar la paradoja de la impropiedad del propio cuerpo. La dominación, que se quiere ilimitada, acaba despojando al sujeto de aquello que en apariencia nada podría arrebatarle: poder expropiador de cuerpos. Esa dinámica desposeedora alcanza su expresión más inmunda en el universo concentracionario: cf. SucASAS, A., «Anatomía del Lager. Una aproximación al cuerpo concentracionario», en: MATE, R., (ed.), La filosofía después del Holocausto, op. cit., pp. 55-73. La pérdida del cuerpo, arrebatado por el poder, es uno de los motivos que atraviesan Más ceniza; Sara lo formula con seca concisión: «Es lo último que te quitan, pero te lo quitan también: tu cuerpo» (J. MaYorga, Más ceniza, op. cit., p. 101). 
te va quitando trozos y lo que te pone en su lugar encaja mal, se descompone tan rápido que solo puedes compensarlo con más y más mentiras. Hasta que un día ya no sabes quién eres ${ }^{30}$.

En Himmelweg, el falseamiento comparece como dispositivo para encubrir la perpetración del Mal. Este es el consejo transmitido a los hipotéticos visitantes del campo de exterminio:

«Permítanme un consejo: nada más salir de aquí, empiecen a olvidar. Y así, cuando lleguen a sus casas, podrán tomar papel y pluma y escribir un bonito informe. Hoy como entonces. Porque eso es lo que les ha impulsado a viajar hasta aquí, hoy como entonces. Ustedes quieren comprobar que sus pesadillas son mentira. (...) Hagan fotografías. Nosotros queremos que hagan fotografías. Y, sobre todo, abran bien los ojos y cuenten al mundo lo que han visto. El mundo necesita saber. Ustedes son los ojos del mundo» ${ }^{31}$.

Ojos que ven y, sin embargo, permanecen ciegos: no se demanda del visitante que oculte lo que ha visto, sino que reproduzca, verbal e icónicamente, su visión... tal cual el interés del dominador la ha modelado. Así, como sentenció Benjamin, el «documento de cultura» también es «documento de barbarie». ¿De dónde proviene esa opacidad inducida en la mirada? Del discurso del vencedor, que obnubila la experiencia de los vencidos.

Esa dinámica perversa es responsable de órdenes sociales en trance de descomposición, camino de la anomia. Ilustran esa entropía las situaciones dramáticas de Más ceniza, Angelus novus o Hamelin ${ }^{32}$. Por no hablar de las piezas que, como Himmelweg o El cartógrafo, se adentran en el infierno concentracionario. En Los yugoslavos, Gerardo elabora una "sociología de la catástrofe» que devuelve el hecho colectivo a la descripción hobbesiana del bellum omnium contra omnes:

«Las calles se llenan de los pasos de los que huyen de otros y de los que persiguen a otros, hay una respiración de animal por toda la ciudad. Ruido de animal dentro de la ciudad dentro de ti. Mires donde mires, tanta fuerza desperdiciada, tanta voluntad perdida ${ }^{33}$.

Enajenación ideológica y tortura de los cuerpos, mentira y violencia. A ese motivo de destrucción se oponen dos contra-temas.

\footnotetext{
$30 \quad$ Ibid.

31 Mayorga, J., Himmelweg, op. cit., p. 316.

32 La primera de esas obras se cierra con la acotación que describe un final catastrófico: «Como si las piernas no la sostuvieran, se deja caer sobre el colchón en la postura que tenía Regine. Ruido de avioneta que se estrella, de espejo que estalla, gritos de dolor y de pánico. Todos se vuelven hacia el público como si fuera el lugar de la catástrofe» (MAYorga, J., Más ceniza, op. cit., p. 110). El gesto colectivo de los actores ejemplifica, por lo demás, uno de los rasgos operantes en la ética de la escritura teatral.

33 Mayorga, J., Los yugoslavos, op. cit., p. 678. La atención a la violencia institucionalizada explica la frecuente presencia de personajes militares (oficiales ciegamente obedecidos por la tropa) en las obras de Mayorga.
} 
Por un lado, en lo que cabría calificar de humanismo residual, Mayorga, tras diagnosticar la degradación de la palabra a manos del poder (entre sus predecesores principales destacarían Karl Kraus, cuando denuncia en la fraseología periodística la inoculación de la indignidad en el lenguaje, y Victor Klemperer al diseccionar, en calidad de filólogo resistente, la Lingua Tertii Imperii), reivindica la redención del verbo como medio de debelar la ignominia instalada en el habla y, en consecuencia, la falsedad imperante en el universo ciudadano. De ahí que la esperanza se asocie tan a menudo a personajes que, a contracorriente de la banalización mediática, se aferran al valor de la palabra y de su registro escrito: el matrimonio de Altos de Animales nocturnos; Copito de Nieve, apasionado lector de Montaigne; Germán, el profesor de El chico de la última fila; Teresa de Jesús. La del lenguaje es problemática central de esa dramaturgia porque en él residen, inextricablemente, el máximo peligro y una «débil esperanza mesiánica»:

«El lenguaje es el asunto político más importante. La doble misión política del teatro, crítica y utópica, empieza por el lenguaje. En el teatro el espectador puede hacer experiencia de la grandeza y la miseria de la palabra. El teatro puede darle a ver qué hacen las personas con las palabras y lo que las palabras hacen con las personas. (...)

Ayudar al espectador a encontrar su propia palabra es una misión, política y moral, del teatro. Más palabra es más vida y más capacidad de resistir» ${ }^{34}$.

Ese potencial develador de la palabra escénica alcanza su culminación en el segundo contra-tema: la recuperación del pasado encubierto, enterrado por los vencedores en un perverso ejercicio de amnesia inducida. Probablemente, la máxima tensión de la dramaturgia mayorguiana se alcance en aquellas piezas cuyo centro argumental está en el apremio de liberar el pasado condenado al olvido y, con ello, restablecer la verdad: presente ya en la primera de sus obras, Siete hombres buenos, prosigue su trayectoria a través del corpus (El jardín quemado, Himmelweg, La tortuga de Darwin...) hasta culminar en El cartógrafo. Inspirándose en Walter Benjamin y Reyes Mate, Mayorga apela sin descanso a un "teatro anamnético» en el que tenga cabida la memoria de los vencidos. Alcanza ahí su plenitud afirmativa. Y recupera para la escena una de las figuras decisivas del pasado siglo: la del testigo que, tras haber sobrevivido a la perpetración de la barbarie, quiebra con su voz la abyecta alianza de silencio y olvido. La Harriet de La tortuga de Darwin, que sabe ver «la historia desde abajo», es su personificación ejemplar. También fray Bartolomé de Las Casas en Primera noticia de la catástrofe.

Al teatro, como a la creación cultural en general, no le es dado impedir que la Catástrofe acontezca... que haya, reiteradamente, acontecido. Pero sí evitar

34 Mayorga, J., Elipses, op. cit., p. 93. Volodia actúa de alter ego de Mayorga cuando declara: «Del teatro espero la verdad. ¿De qué sirve el teatro si no pone ante nosotros aquello que nos ocultamos? ¿De qué sirve si también él se entrega al enmascaramiento del mundo?» (Mayorga, J., El crítico, op. cit., p. 593). 
que el olvido la engulla, dando noticia de ella. Quizá también contribuir a la aparición de núcleos de resistencia ante barbaries venideras, o presentes. A ese doble cometido nos invita la «débil fuerza mesiánica» de Juan Mayorga.

Universidade da Coruña (UDC)

Alberto SucAsas

alberto.sucasas@udc.es

[Aprobado para publicación en enero de 2019] 